\title{
Research of Integration Method of Interpersonal Teaching and Man-machine
}

\author{
Teaching in College English
}

\author{
Zhao Tianyang \\ Teaching Department of College Foreign Languages of Baicheng Normal University, \\ Baicheng City, Jilin Province,China
}

\begin{abstract}
- with the rapid development of hi-tech at present, the college English curriculum teaching of higher education in our country faces an inevitable deep reform and innovation. In order to effectively improve the English application ability of undergraduates, this paper analyzes the integration of interpersonal teaching and man-machine teaching in college English, illustrates the connotation and the current situation of interpersonal and man-machine teaching and makes deep research of integration of these two teaching modes. The author proposes to fully exert the features and advantages of interpersonal teaching and multi-media teaching and hopes to improve the teaching quality of college English through the analysis and research of this paper.
\end{abstract}

Key words- interpersonal teaching; man-machine teaching; college English

\section{INTRODUCTION}

As the examination reform of college English goes deeper and in order to improve the English application ability of undergraduates, the universities have adopted according strategies according to their own characteristics and thus created the good environment for students to conduct autonomous extracurricular learning. In order to guarantee the teaching objectives of higher education and radically guarantee that undergraduates can smoothly have the four-year
English learning at school, the educational department keeps innovating and reforming the teaching mode of college English and finally proposes the teaching mode combining computer teaching and class teaching to teach college English. This is an effective measure to boost the higher education in our country to be globally integrated through innovation. Therefore, college English teaching will have brand-new situations in teaching method, teaching technique and even teaching theory. However, organic integration of interpersonal and man-machine teaching cannot be achieved at once; hence higher requirements must be proposed to teachers and students and the relationship among student, teacher and computer must be fully mastered.

\section{Overview of Interpersonal Teaching}

\section{Current Situation of Interpersonal Teaching}

Interpersonal teaching is a kind of traditional teaching between man and man in class, where student and teacher are face to face with each other. The teaching mode of interpersonal teaching is of great importance to the teaching of college English. In such traditional interpersonal teaching mode, the teacher tends to be at the dominant status and the student at the dominated status; teaching is mainly conducted on the basis of teacher's teaching and 
student's learning. Interpersonal teaching mainly takes the class as the teaching platform, where teacher and student have the communication and interaction of teaching and learning. Most of the teaching hardware of interpersonal teaching is composed of teaching material, teaching aid and blackboard. On the basis of these hardware and facilities, teachers realize their teaching plan and finish the teaching tasks.

The current situation of interpersonal teaching in college English is embodied in the following aspects. First of all, due to the monotonous teaching method, students often take input of language knowledge as the main means to conduct reading, writing and grammatical practice, leading to the poor atmosphere of English learning and the low quality of college English teaching. Second, in such traditional interpersonal teaching, passive phenomena such as 'teacher domination' and 'cramming method' often occur, leading to the closed teaching environment where it is difficult for students to participate in teaching activities and language learning in an active way. Meanwhile, scientific and reasonable teaching situation is hard to be created in teaching, which cannot effectively boost the communication among students and finally hinder the effective implementation of English teaching.

\section{Perfection of Interpersonal Teaching}

First of all, improve the applicability of the teaching materials. The teaching material of college English in our country has remained the same for over a decade. However, the contemporary idea of English teaching must adapt to the integration process of global English teaching, curriculum formulation should be embodied in the reform and innovation of the teaching material and innovation must be realized in the perfection of curriculum system construction, for the perfection of teaching materials can lead the implementation of teaching activities; only when contents of the teaching material are innovative and keep with times can it boost the implementation of English teaching and design of teaching methodology and finally improve the quality of English teaching. Second, strengthen the construction of the teaching team. At present, some teachers do not attach enough importance to the business learning of their majors. We teachers should fully understand the importance that teaching benefits both students and teachers. If we do not effectively improve our own qualities, we cannot keep with the times in the teaching process and it is hard for us to adapt to the college English teaching under New Normal, which will bring many unfavorable factors to English learning of students. College English is of great importance in the public curricula. However, the reduction of teachers' professional levels and qualities will directly influence the teaching quality of college English. Therefore, teachers should regard lifelong learning, constant 'charging' and information update as the new normal in English teaching process. Third, actively adopt the learning method of communication and cooperation. Interpersonal teaching should attach great importance to practice so as to increase students' consciousness of autonomous and cooperative learning. On one hand, make students consciously and active choose the scientific learning methods suitable for them in the process of autonomous learning and make such scientific learning methods keep being perfected and enriched in practice so as to fully exert the active subjective initiative in English learning. In addition, in the process of cooperative 
learning, team spirits, cooperative learning ability, oral and writing ability of students can be greatly strengthened.

\section{Overview of Man-machine Teaching}

\section{Current Situation of Man-machine Teaching}

Man-machine teaching is a new teaching mode with computer as the main carrier produced in order to adapt to the development tendency of informatization. The rapid development of hi-tech brings vast development space to man-machine teaching and precious development opportunities to the reform and innovation of college English teaching of higher education, which is of great significance to the teaching of college English. Man-machine teaching is mainly embodied in the relations among student, teacher and computer, which are closely related to one another; any mistake will lead to the failure of the entire man-machine teaching. At present, there are more successful cases of man-machine teaching, the momentum of which is rapid. Under this teaching mode, it can effectively improve the listening and speaking ability of students, expand their vocabulary and realize the accessible communication of English.

\section{Perfection of Man-machine Teaching}

First of all, further make clear the teaching objective. Implementation of man-machine teaching should fully mobilize the activeness of students and create the good atmosphere of learning and using English. Teachers should not only boost students to gain a large amount of information, but also strengthen students' cognition and understanding of the key and main points so as to reach the ultimate teaching objective. Second, improve students' subjective initiative of learning English. In man-machine teaching, students can choose the learning materials according to their own likeness and demands; man-machine teaching is characteristic of two-way interaction and real-time full interaction, so students can choose any word and sentence to learn. Meanwhile, the learning process is of repeatability. Second, always make summaries and assessment. In man-machine teaching, summary and assessment is of great importance. Hence, teachers should boost the teaching assessment system in the man-machine teaching process and strengthen its scientificity and reasonableness. Teachers should fully motivate the scientificity and fairness of man-machine teaching, for example, to provide supervision and monitoring of the whole learning process of students, to scientifically master and control the proportion of period and score in man-machine learning.

\section{Integration Method of Interpersonal Teaching and Man-machine Teaching of College English}

1. Organic Combination of Interpersonal Teaching, Man-machine Teaching and Multi-media Technique

(1) Organic Combination of Man-machine Teaching and Multi-media Technique

Application of man-machine teaching in the multi-media environment can make the originally rigid basic techniques of English become vivid and better turn the originally abstract language points of English into the collective language points. This teaching design method not only improves students' interest in learning English, but also improves the learning efficiency of students. Although man-machine teaching interaction can help the English teaching, yet it is difficult to realize the 
anticipated effects, if man-machine teaching is not combined with the actuality of English teaching. Therefore, man-machine teaching should be effectively combined with interpersonal teaching and multi-media techniques in the future teaching process so as to keep improving the efficiency of class. Meanwhile, in the teaching process, teachers should fully exert their functions of guidance and have effective teaching through modern teaching modes.

(2) Organic Combination of Interpersonal Teaching and Multi-media Techniques

In terms of the multi-media courseware made by teachers, problems such as overdue contents, few key points and rapid playing speed exist, which severely restrict the activeness of students in learning. Aiming at these phenomena, teachers should exert the main body status of students and guide them; they should take multi-media techniques as an auxiliary mode of teaching rather than completely rely on multi-media. Interpersonal teaching strengthens the communication between teachers and students, but also strengthen teachers' understanding of individual students.

2. Impact of Man-machine Teaching on Teachers and Students

On one hand, for teachers, man-machine teaching keeps increasing the work load and difficulty of teachers; the key points of class teaching turns from illustration of the key and main points of the texts to guidance of students in autonomous learning and helps of students in solving the difficulties; they also pay more attention to the individuality of students and initiative. On the other hand, for students, man-machine teaching can strengthen students' training of writing and translation, good for students to have professional learning of English. For example, teachers can train their oral and listening ability in business English, social English and tourism English through activities such as actual conferences and exhibitions according to the interests and hobbies of students so as to improve the flexibility of English thinking of students.

\section{Innovation of Teaching Mode}

Innovation of teaching mode should both change the teaching idea and the teaching methods and activities so as to realize the transition from teacher-oriented traditional teaching mode to the new teaching mode. Student-oriented innovative teaching mode attaches importance to cultivation of students' language application ability and improvement of students' autonomous learning ability. Therefore, in class teaching of college English, teachers should adopt the new teaching modes and combine them with the modern information technology according to the requirements of the examination reform of college English. Through application of new teaching modes, teachers can make students autonomously choose the materials they need so as to effectively solve the training insufficiency of listening and speaking in traditional teaching. Teachers can also master the learning conditions of students at any time so as to improve the learning initiative of students and finally effectively improve the listening and speaking ability of students.

4. Organic Combination of Interpersonal Teaching and Man-machine Teaching

At present, college English teaching in our country faces profound reform and innovation; through constant integration, the new teaching modes will more and more adapt to the teaching characteristics of college English in universities, 
which will greatly improve undergraduates' English application ability. Therefore, teachers should organically combine the interpersonal teaching and man-machine teaching and fully exert the advantages of knowledge-intensive interpersonal teaching and controllable teaching through the multiple channels and whole interaction of multi-media. On one hand, according to the actual conditions of students and starting from learning control theory, exert the two-way construction of knowledge mastery so as to boost the smooth implementation of interaction teaching in multi-media environment. On the other hand, on the basis of comprehensive assessment, boost interaction between students and teachers through multi-media and finally improve the comprehensive ability of students in English listening, speaking, reading and writing. For example, some universities have began to adopt the teaching mode that combines the traditional interpersonal teaching and multi-media interpersonal teaching; however, influenced by the long-term'teaching and learning' mode ingrained in the minds of teachers and students, it always causes disorder in the class teaching. Hence, these two teaching modes should be well combines and mutually boost.

\section{Conclusion}

integration of interpersonal teaching and organic teaching is of great importance to teaching of college English, which can effectively improve the English application ability of undergraduates. Teachers should organically combine the teaching modes of interpersonal teaching and organic teaching. On one hand, they should fully exert the function of interpersonal teaching focusing on language input; on the other hand, they should also make good use of multi-media teaching, making the advantages of language output such as diversity, real context and large amount of information effectively serve the class teaching of college English so as to make college English teaching form the two-way interactive teaching mode.

\section{Reference:}

[1] Zhao Chunmei. Integration Strategy of Interpersonal Teaching and Organic Teaching of College English [J] Journal of Lanzhou Institute of Education, 2013, 09:51-52.

[2] Zhu Sanmao. On 'Man-machine' and 'Interpersonal' Relationships in 'Class+Network' Stereo Teaching Mode of College English [J] Campus English, 2015, $19: 35$

[3] Li Fabin. Analysis of English Teaching Methodology of Training Obstacle Reform in English Learning of Students in Higher Vocational Colleges $[\mathrm{J}]$ Education and Vocation, 2009 (23)

[4] Wu Ke. Analysis of Psychological State of English Learning of Students in Higher Vocational Colleges and Teaching Solutions [J] Academic Exchanges, 2012 (14) 